\title{
REVIEW
}

\section{A review of the use of propofol for procedural sedation in the emergency department}

\author{
L Symington, S Thakore
}

Emerg Med J 2006;23:89-93. doi: 10.1136/emj.2005.023713

Sedation for short but potentially painful procedures is often undertaken in the emergency department. The ideal sedative regimen should provide analgesia and anxiolysis with minimal side effects and cardiorespiratory depression and rapid recovery post-procedure. Propofol has found increasing popularity with anaesthetists for sedation in the operating theatre. This is a review of the current literature looking at the use of propofol for procedural sedation in the emergency department. A comprehensive literature search of Medline from 1966 to week 4 of 2005, Embase from 1980 to week 10 of 2005, and the Cochrane Library was carried out using the OVID interface. Eight articles were selected for review. The evidence suggests that propofol is both effective and safe to use in the emergency department. However, several of the papers reviewed used deep levels of sedation that are not recommended in the UK by non-anaesthetists.

See end of article for authors' affiliations

Correspondence to:

Dr L Symington, Accident and Emergency

Department, Ninewells

Hospital, Dundee DD1 9SY, UK; linda.r. symington@tuht.scot.nhs. uk

Accepted 5 June 2005
$\mathrm{P}$ atients who are in pain or anxious and require potentially painful procedures are frequently seen in the emergency department (ED). Annual figures from the ED in Ninewells Hospital suggest that $0.8 \%$ of presenting patients undergo sedation for closed orthosedation related morbidity and mortality in other areas have shown a significant rate of complications. Endoscopy has a reported morbidity rate of 1 in 200 and mortality rate of 1 in 2000. ${ }^{1}$ These adverse events were closely linked to high doses of sedative and lack of monitoring. The Scottish Audit of Surgical Mortality in 1996 concluded that a number of deaths had occurred during endoscopy due to oversedation, and recommended a national audit. ${ }^{2}$

Guidelines from the UK Academy of Medical Royal Colleges and their Faculties have recommended levels of staffing, experience, training, and equipment that should be available for adults undergoing sedation by non-anaesthetists. $^{3}$ The guidelines from the Scottish Intercollegiate Guidelines Network for sedation in children have been recently revised and only specifically recommend nitrous oxide for sedation in the ED. ${ }^{4}$ Conscious sedation is recommended, as deeper levels of sedation require a level of care identical to that of general anaesthesia, and are associated with increased risk in an emergency setting where patients may not be fasted or have the benefit of full pre-assessment. paedic reduction or suturing. Studies looking at
The guidelines suggest that sympathetic patient management and counselling, along with expert clinical management, may minimise the need for therapeutic sedation and therefore reduce risks. Careful overview and audit are advised, but few results have been published.

The aim of drugs used in sedation is to relieve both pain and anxiety while avoiding cardiorespiratory depression or loss of airway reflexes. Analgesics and sedative agents are both required, but it must be remembered that these drugs have synergistic effects. All drugs currently in use for sedation have potential for adverse effects, particularly impaired respiration or circulation. The ideal drug regimen would have few side effects, a short duration of action, and acceptable safety margins.

Ketamine and propofol were not recommended for use by non-anaesthetists by the UK Academy of Medical Royal Colleges and their Faculties because of insufficient evidence of their use in this area. However, several studies examining the performance of propofol in the ED have been published recently.

\section{CHARACTERISTICS OF PROPOFOL}

Most conditions requiring procedural sedation in the ED are painful. The removal of painful stimulus before these drugs have reached peak effect can lead to oversedation. Propofol seems an appealing drug for use in this area with a rapid onset and offset effect. However, a narrow therapeutic index has previously been observed, which leads to a risk of progression into deep sedation. ${ }^{5}$

Propofol (2,6 di-isopropylphenol) is a very short acting non-opioid sedative-hypnotic agent. It is thought to work by potentiating the binding of $\gamma$-amino butyric acid to receptor sites in the central nervous system (CNS). ${ }^{6}$ It has no analgesic properties and must be used in conjunction with adequate pain relief. Studies vary regarding the extent of amnesic properties compared to benzodiazepines. ${ }^{67}$ but it has recognised antiemetic and euphoric effects. Onset of action is $<60$ seconds (one arm-brain circulation). Despite a half life of 13-44 hours, duration of action is approximately 10 minutes, owing to rapid redistribution from CNS tissue to muscle and fat. Metabolic clearance equals or exceeds hepatic blood flow, suggesting extrahepatic clearance, possibly pulmonary. ${ }^{6}$ Pharmacokinetics are unaffected by renal or hepatic disease but dose reduction is required

Abbreviations: CNS, central nervous system; ED, emergency department 
in the elderly, ${ }^{6}$ as volume of distribution falls with age.

Recently there have been several studies looking at the use of propofol by non-anaesthetists with promising results. These studies have shown rapid recovery times and favourable safety profiles when comparing propofol with midazolam in endoscopy. ${ }^{8-10} \mathrm{~A}$ further study found the incidence of adverse events in elderly patients to be low and similar to that of a control group of younger patients. ${ }^{11}$ The safe use of propofol has been reported by dentists ${ }^{12}$ and for termination of pregnancy by gynaecologists. ${ }^{13}$ Geunther et al found propofol given by emergency physicians for elective sedation in a paediatric short stay unit to be effective and safe, despite a study population with significant underlying systemic disease (90\% with ASA score of III). ${ }^{14}$

So, in a patient requiring procedural sedation in A\&E is propofol a safe and effective option?

\section{EVIDENCE OF THE USE OF PROPOFOL IN EMERGENCY DEPARTMENT SEDATION PROCEDURES \\ Methods}

A comprehensive literature search was carried out using: (a) Medline 1966 to week 4 of 2005 and Embase 1980 to week 10 of 2005 using the OVID interface, and the following keywords: (exp propofol/or propofol.mp. OR "hypnotics and sedatives"/or sedative.mp. OR diprivan mp. AND sedation.mp. OR exp conscious sedation/or procedural sedation.mp. OR manipulation mp. OR exp manipulation orthopaedic OR exp dislocations OR exp electric countershock AND expemergencies/or emergency.mp. OR exp emergency medicine/or emergency.mp.) LIMIT to English language LIMIT to human LIMIT to abstracts; and $(b)$ the Cochrane Library. From this search, 195 papers were identified on Medline, 34 on Embase, and 5 in the Cochrane Central Register of Controlled Trials. From the Medline results, 185 papers were excluded because their abstracts revealed them to have no direct relevance to the topic, or they were found to be reviews, case reports, or comments. The Embase search found six duplicates. Of the five papers from the Cochrane database, one was a duplicate and four were not relevant to the topic. Two papers by Miner et al looking at bispectral $\mathrm{EEG}^{15}$ analysis and end tidal carbon dioxide monitoring ${ }^{16}$ in procedural sedation compare propofol to other medication but with small numbers and no attempt to randomise or explain choice of drug used. Therefore, these papers were discarded after further reading.

Thus, eight articles were selected for further review. Four controlled trials look at the use of propofol sedation in an emergency setting. A further four descriptive trials assess safety and effectiveness of propofol for procedural sedation in the ED.

Swanson et al $^{17}$ (table 1) prospectively studied a convenience sample of 20 patients aged 19-62 years undergoing a variety of painful procedures. All were pre-medicated with fentanyl then given an infusion of propofol at $0.21 \mathrm{mg} / \mathrm{kg} /$ min until ptosis and slurred speech occurred, and were then maintained with 3-6 mg/kg/h. No information was given as to the achieved depth of sedation. All patients received supplementary oxygen by nasal cannulae. The hypotension recorded in one patient resolved with no intervention, and the two episodes of apnoea resolved within 30 seconds with one intervention of assisted ventilation.

Skokan et al $^{18}$ (table 1) report a prospective study of 40 paediatric patients requiring minor surgical and orthopaedic procedures. Morphine was given for analgesia on arrival or fentanyl pre-procedure and all patients were fasted for 6 hours. Propofol was given $(1 \mathrm{mg} / \mathrm{kg}$ then $0.5 \mathrm{mg} / \mathrm{kg}$ as required) with an end point of tolerance of pain with no purposeful verbalisation or movement interfering with the procedure. No scale for depth of sedation was used but deep sedation was anticipated. Hypotension was observed in "most" patients, but reported to be transient in $92 \%$. The authors state there was no evidence of poor perfusion as demonstrated by delayed capillary refill, weak peripheral pulse, or tachycardia. This may be misleading, as hypotension with propofol is associated with peripheral vasodilatation. More than half $(57 \%)$ of patients had fully recovered by 10 minutes and no patient reported recall of the procedure at 24 hours. Most (95\%) of parents and $93 \%$ of physicians also rated the sedation procedure as excellent.

Bassett et $a l^{19}$ (table 1) is a further study in the same institution following almost the same protocol. Patients were fasted for 3 hours and 10 litres of oxygen was administered routinely. At least three deviations from protocol were noted when patients were not given oxygen, and all of these patients became hypoxic. One patient vomited after the procedure with no evidence of aspiration. Efficacy was defined only by successful completion of the procedure excluding technical problems with reductions. No measure of patient discomfort or satisfaction was recorded.

Pershad et $a^{20}$ (tables 1,2 ) is a retrospective review of the case notes of 52 patients identified by a pharmacy database. Of these, $81 \%$ received opiate analgesia pre-procedure and $71 \%$ were given supplementary oxygen. All the sedation procedures were felt to have been satisfactory and a low rate of adverse events is reported.

Havel et $a l^{21}$ (table 3) conducted a randomised, blinded controlled trial comparing propofol with midazolam. Patients were not fasted and routine supplementary oxygen was not given. All received morphine for analgesia and were randomised to a sedative agent. Propofol was given as a $1 \mathrm{mg} / \mathrm{kg}$ bolus followed by infusion of $67-100 \mu \mathrm{g} / \mathrm{kg}$.As shown in table 4 , the propofol group had a significantly shorter recovery time $(p=<0.001)$. Sedation was aimed at a Ramsay Scale score of 4-5 (table 5). There was no statistically significant difference found in the depth of sedation or rate of complications between the two groups, and the overall rate of adverse events was low.

Patient distress was not directly assessed. Immediate recall was higher in the propofol group but no statistical difference was found at 24 hours. However, only $72.1 \%$ of the propofol group and $54.3 \%$ of the midazolam group were reached for this follow up. Only one patient was noted to have clear recall of pain.

Godambe et $a^{22}$ (table 3) undertook a trial of 113 paediatric patients requiring orthopaedic procedures in the ED. Oxygen was only given for hypoxia and fasting was for 4 hours. Patients were randomised to receive $1-2 \mu \mathrm{g} / \mathrm{kg}$ fentanyl and propofol ( $1 \mathrm{mg} / \mathrm{kg}$ then unspecified aliquots) or ketamine and midazolam as boluses. Delayed effects only occurred in the ketamine/midazolam group $(10 \%)$ and consisted of dysphoric reactions and nausea.

Effectiveness was measured by several assessments. An Observational Scale of Behavioral Distress (Revised) score was given by one of two reviewers blinded to the drug used after watching a videotape of the procedure. There was a significant difference between the groups in this scoring, but both scores were very low, meaning very little clinical difference. The sedation nurse documenting and the surgeon performing the procedure expressed similar preference for either drug. Patient and parent responses showed no statistical difference in expressed satisfaction or recall.

Miner et al ${ }^{23}$ (table 3) compared propofol with methohexital in a study of 103 adult patients undergoing fracture and dislocation reduction.. Supplementary oxygen was given at the physician's discretion. Analgesia was given as per the usual policy in the department. Propofol was given as $1 \mathrm{mg} /$ $\mathrm{kg}$ bolus then $0.5 \mathrm{mg} / \mathrm{kg}$. The only specified aim of sedation 
Table 1 Descriptive studies

\begin{tabular}{|c|c|c|c|c|}
\hline Author & No. of patients & Type of study & Outcome measures & Weakness \\
\hline \multirow[t]{3}{*}{ Swanson et al ${ }^{77}$} & \multirow{3}{*}{$\begin{array}{l}20 \text { patients undergoing a } \\
\text { variety of painful } \\
\text { procedures }\end{array}$} & \multirow[t]{3}{*}{$\begin{array}{l}\text { Prospective, descriptive study } \\
\text { of convenience sample }\end{array}$} & $\begin{array}{l}\text { Sedation/recovery } \\
\text { times }\end{array}$ & Not controlled; small numbers \\
\hline & & & Rate of adverse events & $\begin{array}{l}\text { No measured depth sedation; no mention of prior } \\
\text { analgesia given or fasting status }\end{array}$ \\
\hline & & & $\begin{array}{l}\text { Patient/physician } \\
\text { satisfaction }\end{array}$ & Only $80 \% 24$ hour follow up \\
\hline \multirow[t]{4}{*}{ Skokan et $a f^{18}$} & \multirow{4}{*}{$\begin{array}{l}40 \text { paediatric patients a } \\
\text { variety of painful } \\
\text { procedures }\end{array}$} & \multirow{4}{*}{$\begin{array}{l}\text { Prospective, descriptive study } \\
\text { of convenience sample }\end{array}$} & Time to recovery & Not controlled; small numbers \\
\hline & & & Rate of adverse events & No measured depth sedation \\
\hline & & & Patient/parent and & Subjective endpoints for sedation and recovery; \\
\hline & & & operator satisfaction & $\begin{array}{l}\text { confusing presentation of results; inconsistent } \\
\text { protocol for O2; use of IV fluids not standardised }\end{array}$ \\
\hline \multirow[t]{2}{*}{ Bassett et al ${ }^{19}$} & \multirow[t]{2}{*}{$\begin{array}{l}393 \text { sedation events ( } 392 \\
\text { paediatric patients) }\end{array}$} & \multirow[t]{2}{*}{$\begin{array}{l}\text { Prospective descriptive study } \\
\text { of consecutive patients }\end{array}$} & $\begin{array}{l}\text { Time to sedation, } \\
\text { recovery, discharge }\end{array}$ & $\begin{array}{l}\text { Not controlled; included some very long } \\
\text { procedures }\end{array}$ \\
\hline & & & Rate of adverse events & $\begin{array}{l}\text { No record of patient distress/satisfaction; } \\
\text { confusing presentation of results; deviations form } \\
\text { preoxygenation and fasting protocols; use of IV } \\
\text { fluids not standardised }\end{array}$ \\
\hline \multirow[t]{2}{*}{ Pershad et $a^{P^{0}}$} & \multirow{2}{*}{$\begin{array}{l}52 \text { paediatric patients } \\
\text { undergoing a variety of } \\
\text { painful procedures }\end{array}$} & \multirow[t]{2}{*}{$\begin{array}{l}\text { Retrospective case note } \\
\text { review }\end{array}$} & $\begin{array}{l}\text { Times to recovery, } \\
\text { discharge }\end{array}$ & Not controlled \\
\hline & & & Rate of adverse events & $\begin{array}{l}\text { Retrospective - relies on accurate documentation } \\
\text { in notes; no record of patient distress/satisfaction }\end{array}$ \\
\hline
\end{tabular}

was a bispectral analysis score of 70-85 based on previous work by the same group. ${ }^{19}$ No significant difference was found in the level of sedation, rate of adverse effects, respiratory depression (as measured by use of oximetry and end tidal carbon dioxide), or expressed patient satisfaction (table 4).

Coll-Vincent et $a^{24}$ (table 3) compared propofol, etomidate, midazolam and midazolam and flumazenil in a trial of 32 adult patients undergoing cardioversion for atrial fibrillation or flutter. Depth of sedation was left to the discretion of the physician and all patients were sedated to Ramsay scale level 6. A significantly shorter recovery time occurred with propofol compared with all groups except midazolam/ flumazenil; in this group all patients became re-sedated when flumazenil was stopped. There was no significant difference in adverse effects except for marked myoclonus in four of the etomidate group. Satisfaction was rated highest in the etomidate and propofol groups.

\section{DISCUSSION}

The observational studies above show impressive safety profiles with propofol. In particular, the study by Bassett et al observed large numbers over a period of 2 years and demonstrated no significant morbidity. However, without a control group we cannot know if this reflects good sedation practice rather than the characteristics of the drug itself. High rates of minor events were reported, including transient hypoxia, but these are similar to rates previously reported with midazolam in a paediatric ED setting, ${ }^{25}$ and may reflect the apparently deep levels of sedation used. Skokan et al and Bassett et al describe tolerance of noxious stimulus without complaint, which may be deep sedation or general anaesthesia. In a paediatric population, this may be necessary for procedures to be performed. No episodes of aspiration occurred, but patients were not consistently fasted if procedures were determined to be urgent.

The reduction of hypoxia from $30 \%$ to $5 \%$ when routine oxygen is administered suggests that this should be standard practice with propofol. It is suggested that this may mask respiratory depression, which may be demonstrated by $\mathrm{ETCO}_{2}$ monitoring. Miner et al observed a significant rate of respiratory depression by their definition using $\mathrm{ETCO}_{2}$, but no associated morbidity or major adverse events. They speculate that these criteria identify patients at risk of significant clinical respiratory depression. Therefore, $\mathrm{ETCO}_{2}$ monitoring may help avoid oversedation.

The controlled studies all seem to show favourable safety profiles when propofol is compared when several other sedative agents, but many of these agents would not be considered for sedation in most UK EDs. The study of Havel et al compares propofol with midazolam and aims for a Ramsay sedation score of 4-5 (table 5). With this protocol, propofol

Table 2 Descriptive studies: key results and complications

\begin{tabular}{|c|c|c|c|c|}
\hline & Swanson et al & Skokan et al & Bassett et al & Pershad et al \\
\hline No. of patients & 20 & 40 & 393 & 52 \\
\hline Dose of propofol & $\begin{array}{l}\text { Infusion } 0.21 \mathrm{mg} / \mathrm{kg} / \mathrm{min} \text { then } 3 \text { - } \\
6 \mathrm{mg} / \mathrm{kg} / \mathrm{h}\end{array}$ & $\begin{array}{l}1 \mathrm{mg} / \mathrm{kg} \text { then } 0.5 \mathrm{mg} / \mathrm{kg} \\
\text { boluses }\end{array}$ & $\begin{array}{l}1 \mathrm{mg} / \mathrm{kg} \text { then } 0.5 \mathrm{mg} / \mathrm{kg} \\
\text { boluses }\end{array}$ & $\begin{array}{l}1 \mathrm{mg} / \mathrm{kg} \text { then } 0.5 \mathrm{mg} / \mathrm{kg} \\
\text { boluses }(\mathrm{Cl} \text { for longer } \\
\text { procedures) }\end{array}$ \\
\hline Hypoxia & $5 \%$ & $\begin{array}{l}30 \% \text { (none when given } \\
\text { supp O2) }\end{array}$ & $\begin{array}{l}5 \% \text { (at least } 3 \text { patients not } \\
\text { given supplementary } \mathrm{O} 2 \text { ) }\end{array}$ & $5.8 \%$ \\
\hline Apnoea/BVM & $10 \%$ & $2.5 \%(20$ secs $)$ & $0.8 \%(<60$ secs $)$ & 0 \\
\hline Hypotension & $5 \%$ & $\begin{array}{l}\text { Most patients (mean } \\
\text { change SBP }-18 \mathrm{mmHg} \text { ) }\end{array}$ & $\begin{array}{l}84 \% \text { but transient in } 93 \% \text { of } \\
\text { these }\end{array}$ & 0 \\
\hline Arrhythmia & 0 & 0 & $6 \%$ bradycardia all transient & 0 \\
\hline Pain on injection & $20 \%$ & $5 \%$ & Not recorded & 0 \\
\hline Depth of sedation & Conscious sedation & Deep sedation & Deep sedation & Deep sedation \\
\hline Patient satisfaction & $\begin{array}{l}\text { All expressed willingness to have } \\
\text { drug again }\end{array}$ & $100 \%$ "excellent" & Not recorded & Not recorded \\
\hline Mean recovery times & $6.1 \mathrm{~min}$ & $18 \mathrm{~min}$ & $18 \mathrm{~min}$ & $27.1 \mathrm{~min}$ \\
\hline
\end{tabular}


Table 3 Randomised controlled studies

\begin{tabular}{|c|c|c|c|c|}
\hline Author & No, of patients & Type of study & Outcome measures & Weakness \\
\hline Havel et $a^{21}$ & $\begin{array}{l}91 \text { paediatric patients; } \\
\text { isolated extremity } \\
\text { closed fracture } \\
\text { reduction }\end{array}$ & $\begin{array}{l}\text { Prospective, blinded, } \\
\text { randomised, controlled trial } \\
\text { comparing propofol (with } \\
\text { lignocaine } 2 \% \text { ) and midazolam }\end{array}$ & $\begin{array}{l}\text { Depth of sedation } \\
\text { (Ramsay scale) } \\
\text { Timings to sedation, } \\
\text { recovery and discharge } \\
\text { Rate of adverse events }\end{array}$ & $\begin{array}{l}\text { Small numbers (power calculated for recovery times only) } \\
2 \text { patients excluded due to infusion equipment failure } \\
\text { No record of patient distress/satisfaction; IV lignocaine } \\
\text { in propofol group only; poor response at follow up } \\
\text { (72.1\% propofol, } 54.3 \% \text { midazolam) }\end{array}$ \\
\hline Godambe et $a^{P^{2}}$ & $\begin{array}{l}113 \text { paediatric } \\
\text { patients undergoing } \\
\text { emergency } \\
\text { orthopaedic } \\
\text { procedure }\end{array}$ & $\begin{array}{l}\text { Prospective, partially blinded } \\
\text { controlled trial comparing } \\
\text { propofol/fentanyl and } \\
\text { ketamine/midazolam }\end{array}$ & $\begin{array}{l}\text { Timings of sedation, } \\
\text { procedure, recovery } \\
\text { Rate of adverse events/ } \\
\text { interventions } \\
\text { OSBD-R score } \\
\text { Ortho/sedation nurse/ } \\
\text { parent satisfaction patient } \\
\text { recall }\end{array}$ & $\begin{array}{l}\text { Small numbers (power calculated for OBSD-R scores) } \\
\text { Randomisation alternate days } \\
\text { Only video observer and parents/patient blinded } \\
3 \text { patients had no OSBD-R, } 1 \text { not included in recovery } \\
\text { time analysis; subjective assessment of depth of sedation }\end{array}$ \\
\hline Miner et $a P^{3}$ & $\begin{array}{l}109 \text { patients } \\
\text { undergoing fracture/ } \\
\text { dislocation reduction }\end{array}$ & $\begin{array}{l}\text { Prospective, randomised trial } \\
\text { comparing propofol and } \\
\text { methohexital }\end{array}$ & $\begin{array}{l}\text { Depth of sedation } \\
\text { Rate of respiratory } \\
\text { depression (RD)/adverse } \\
\text { events } \\
\text { Patient satisfaction/VAS }\end{array}$ & $\begin{array}{l}6 \text { patients excluded for incomplete data collection; } \\
\text { confusing presentation of results }\end{array}$ \\
\hline $\begin{array}{l}\text { Coll-Vincent et } \\
a^{p^{4}}\end{array}$ & $\begin{array}{l}32 \text { patients } \\
\text { undergoing } \\
\text { cardioversion }\end{array}$ & $\begin{array}{l}\text { Prospective, randomised } \\
\text { controlled trial comparing } \\
\text { propofol, Etomidate, midazolam } \\
\text { and midazolam/flumazenil }\end{array}$ & $\begin{array}{l}\text { Times to sedation and } \\
\text { recovery } \\
\text { Rate of adverse events } \\
\text { Patient satisfaction/ } \\
\text { ordinal scale }\end{array}$ & $\begin{array}{l}\text { Small numbers } \\
\text { Not blinded (attempt to correct with objective outcomes) }\end{array}$ \\
\hline
\end{tabular}

IV, intravenous; OSBD-R, Observational Scale of Behavioral Distress, Revised; RD, respiratory depression.

caused similar rates of hypoxia and less oversedation than midazolam, although these did not reach statistical significance. Although significant morbidity was not demonstrated in any study, high rates of hypoxia were found, sometimes requiring airway support or assisted ventilation. This again may reflect use of sedation levels far deeper than conscious sedation in several studies.

Patients were fasted in some of these studies. This is not always possible in an emergency situation. Potential loss of protective airway reflexes and the use of assisted ventilation must be avoided if aspiration is to be prevented. Propofol may not be as reliable at achieving a set depth of sedation at lesser levels, and greater differences in rates of adverse events may then be seen. Rapid recovery times are consistent in all of these studies and some authors postulate that this may reduce risk if oversedation does occur. However, this is not proven in the current literature.

Efficacy of propofol is demonstrated, with consistently high patient and physician satisfaction scores and low distress scores. Immediate recall was noted to be higher when compared with midazolam in the study of Havel et al, but recall at 24 hours was similar, and only one patient reported clear recall of discomfort.

All of the studies differ in their protocols and dosage/ administration of drugs, including co-administration of varying doses and types of analgesia. No marked difference is observed between use of propofol by infusion or bolus. A safe dosing regimen is therefore not apparent, although most started with a dose of $1 \mathrm{mg} / \mathrm{kg}$ followed by titration of smaller doses to effect. As infusion devices such as target controlled infusion and patient controlled devices become more sophisticated, these may offer a greater control and safety margin..$^{26}$

Emergency practitioners have demonstrated safe practice in relation to advanced airway skills. ${ }^{28}$ However, these skills may not help if a devastating aspiration was to occur due to oversedation of a patient who is not fasted, and previous assessment of knowledge of sedation guidelines and drugs has shown disappointing results. ${ }^{29}$ Safe sedation relies upon adequate training of the practitioner, thorough preparation of the patient, and observance of established guidelines. Therapeutic sedation should not be an alternative to a compassionate approach and good patient counselling, which

Table 4 Randomised controlled studies: key results and complications

\begin{tabular}{|c|c|c|c|c|c|c|c|c|}
\hline \multirow[b]{2}{*}{ No. of patients } & \multicolumn{2}{|l|}{ Havel ef al } & \multicolumn{2}{|c|}{ Godambe ef al } & \multicolumn{2}{|l|}{ Miner et al } & \multicolumn{2}{|c|}{ Coll-Vincent et al } \\
\hline & $\begin{array}{l}43 \text { propofol } \\
\text { infusion }\end{array}$ & $\begin{array}{l}46 \\
\text { midazolam }\end{array}$ & $\begin{array}{l}59 \\
\text { propofol/ } \\
\text { fentanyl } \\
\text { bolus }\end{array}$ & $\begin{array}{l}54 \\
\text { ketamine/ } \\
\text { midazolam }\end{array}$ & $\begin{array}{l}52 \text { propofol } \\
\text { bolus }\end{array}$ & 51 methohexital & $\begin{array}{l}9 \text { propofol } \\
\text { bolus }\end{array}$ & $\begin{array}{l}9 \text { etomidate, } 8 \\
\text { midazolam, } 6 \\
\text { midazolam/ } \\
\text { flumazenil }\end{array}$ \\
\hline Hypoxia & $11.6 \%$ & $10.9 \%$ & $30 \%$ & $7.4 \%$ & Not recorded & Not recorded & $44 \%$ & $11 \%-33 \%$ \\
\hline $\begin{array}{l}\text { Hypo-ventilation/apnoea/ } \\
\text { BVM }\end{array}$ & 0 & 0 & 0 & 0 & $3.63 \%$ & $7.4 \%$ & $22 \%$ & $16.6 \%-37.5 \%$ \\
\hline Hypotension & 0 & 0 & $1.6 \%$ & 0 & 0 & 0 & 0 & 0 \\
\hline Arrhythmia & 0 & 0 & 0 & 0 & 0 & 0 & & \\
\hline Pain on injection & $7 \%$ & $4.3 \%$ & $3.3 \%$ & 0 & Not recorded & Not recorded & 0 & $0-44 \%$ \\
\hline $\begin{array}{l}\text { Effectiveness/patient } \\
\text { satisfaction }\end{array}$ & $\begin{array}{l}\text { Recall } 20 \% \\
\text { immediate }\end{array}$ & $\begin{array}{l}\text { Recall } 8.6 \% \\
\text { immediate }\end{array}$ & $\begin{array}{l}\text { OSBD-R } \\
0.278\end{array}$ & $\begin{array}{l}\text { OSBD-R } \\
0.084\end{array}$ & Recall 12\% & Recall 17\% & $\begin{array}{l}77 \% \text { very } \\
\text { satisfied }\end{array}$ & $\begin{array}{l}33 \%-77 \% \text { very } \\
\text { satisfied }\end{array}$ \\
\hline & $\begin{array}{l}16 \% \text { at } \\
24 \text { hours }\end{array}$ & $\begin{array}{l}8 \% \text { at } \\
24 \text { hours }\end{array}$ & Recall 0 & Recall 0 & $\begin{array}{l}\text { Satisfaction } \\
88 \%\end{array}$ & $\begin{array}{l}\text { Satisfaction } \\
87 \%\end{array}$ & & \\
\hline Recovery time & $14.9 \mathrm{~min}$ & $76.4 \mathrm{~min}$ & 20.8 & 54.2 & $9.9 \mathrm{~min}$ & $8.5 \mathrm{~min}$ & $10 \mathrm{~min}$ & $5-45 \mathrm{~min}$ \\
\hline
\end{tabular}

OSBD-R, Observational Scale of Behavioral Distress, Revised; 


\section{Table 5 Ramsay Sedation Scale}

\section{Awake}

1 Anxious, agitated, restless

2 Cooperative, orientated, tranquil

3 Responds to commands only

Asleep

4 Brisk response to light glabellar tap or loud auditory stimulus

5 Sluggish response to light glabellar tap or loud auditory stimulus

6 No response to light glabellar tap or loud auditory stimulus

should be adopted in every case. No drug can be expected to compensate for unsafe practice.

\section{CONCLUSION}

The available evidence would seem to imply that propofol can be used safely and effectively in the ED. However, much of the available evidence comes from studies that appear to use deep sedation or possibly general anaesthesia. These levels of sedation are not recommended for non-anaesthetists in the UK, and could be considered dangerous in a situation where patients may not be fasted or fully prepared pre-procedure. Further studies would be required to assess safe use of propofol to achieve levels of sedation currently recommended in UK departments.

\section{KEY POINTS}

- Supplemental oxygen should be given to patients receiving propofol.

- Close monitoring of $\mathrm{O} 2$ saturation, respiration, pulse and blood pressure are essential.

- A safe dosage/administration technique is not clear from these studies though most used a starting dose of $1 \mathrm{mg} / \mathrm{kg}$ and titrate further doses. Target controlled and patient controlled systems may improve safety in the future.

- Many of the studies reviewed use levels of sedation deeper than those recommended for non anaesthetists .

- Recovery times are consistently short (up to five time shorter than midazolam).

- Side effects profiles are comparable or better with propofol.

- Patient and physician satisfaction are consistently high.

- Further studies are suggested looking at propofol for conscious sedation.

\section{Authors' affiliations}

L Symington, S Thakore, Accident and Emergency Department,

Ninewells Hospital, Dundee, UK

Competing interests: there are no competing interests

\section{REFERENCES}

1 Quine MA, et al. Prospective audit of upper gastrointestinal endoscopy in two regions of England: safety, staffing and sedation methods. Gut 1995;36:462-7.

2 Scottish Audit of Surgical Mortality. Annual report 1996.

3 UK Academy of Medical Royal Colleges and their Faculties. Implementing and ensuring safe sedation practice, Report of an Intercollegiate Working Party chaired by the Royal College of Anaesthetists, 2000.

4 Scottish Intercollegiate Guidelines Network. Safe sedation of children undergoing diagnostic and therapeutic procedures 2004.

5 American Society of Anaesthesiologists. Practice guidelines for sedation and analgesia by non-anesthesiologists. Anaesthesiology 2002;96:1004-17.

6 Bryson HM, Fulton BR, Faulds D. Propofol: An update of its use in anaesthesia and conscious sedation. Drugs 1995;50:513-59.

7 Veselis R, Feschenko V, Wronski M. The comparative amnestic effects of midazolam, propofol, thiopental and fentanyl at equisedative concemtrations. Anaesthesiology 1997;87:749-64.

8 Jung $M$, Hofmann C, Kiesslich R, et al. Improved sedation in diagnostic and therapeutic ERCP: propofol is an alternative to midazolam. Endoscopy 2000;32:233-8.

9 Wehrmann T, Kokabpick S, Lembcke B, et al. Efficacy and safety of intravenous propofol sedation during routine ERCP: a prospective, controlled study. Gastrointest Endosc June, 1999;49:677-83.

10 Sipe BW, Rex DK, Latinovich D, et al. Propofol versus midazolam/meperidine for outpatient colonoscopy: Administation by nurses supervised by endoscopists. Gastrointest Endosc 2002;55:815-25.

11 Heuss LT, Schneiper P, Drewe J, et al. Conscious sedation with propofol in elderly patients: a prospective evaluation. Aliment Pharmacol Ther 2003;17:1493-501.

12 Ruiz K, Coldwell SA, Hitchin, et al. Propofol sedation in general dental practice: the first 100 patients. Dent Update 2000;27:16-20.

13 Department of Health Expert Group. Conscious sedation in the termination of pregnancy, 2002.

14 Geunther E, Pribble CG, Junkins EP, et al. Propofol sedation by emergency physicians for elective paediatric outpatient procedures. Ann Emerg Med 2003;42:783-91.

15 Miner JR, Biros MH, Heegaard W, et al. Bispectral electroencephalographic analysis of patients undergoing procedural sedation in the emergency department. Acad Emerg Med 2003; 10:638-43.

16 Miner JR, Heegaard W, Plummer D. End-tidal carbon dioxide monitoring during procedural sedation. Acad Emerg Med 2002;9:275-80.

17 Swanson ER, Seaberg DC, Mathias S. The use of propofol for sedation in the emergency department. Acad Emerg Med 1996;3:234-8.

18 Skokan EG, Pribble C, Bassett KE, et al. Use of propofol in a paediatric emergency department: a prospective study. Clin Paediatr 2001;40:663-71.

19 Bassett KE, Anderson JL, Pribble CG, et al. Propofol for procedural sedation in children in the emergency department. Ann Emerg Med 2003;42:773-82.

20 Pershad J, Sandip A, Godambe. Propofol for procedural sedation in the paediatric emergency department. J Emerg Med 2004;27:11-14.

21 Havel CJ, Strait RT, Hennes H. A clinical trial of propofol versus midazolam for procedural sedation in a paediatric emergency department. Acad Emerg Med 1999:6:989-97.

22 Godambe SA, Elliot V, Matheny D, et al. Comparison of propofol/fentanyl versus ketamine/midazolam for brief orthopaedic procedural sedation in a paediatric emergency department. Paediatrics 2003;112:116-23.

23 Miner JR, Biros M, Johnson C, et al. Randomized clinical trial of propofol versus methohexital for procedural sedation in the emergency department. Acad Emerg Med 2003; 10:931-7.

24 Coll-Vincent B, Sala X, Fernandez C, et al. Sedation for cardioversion in the emergency:analysis of effectiveness in four protocols. Ann Emerg Med 2003;42:767-72.

25 Kennedy RM, Porter FL, Miller P, et al. Comparison of fentanyl/midazolam with ketamine/midazolam for pediatric orthopedic emergencies. Pediatrics 1998; 102:956-63.

26 Glen JB. The development of "Diprifusor": a TCl system for propofol. Anaesthesia 1998;53(suppl 1):13-21.

27 Henderson F, Absalom AR, Kenny GNC. Patient-maintained propofol sedation: a follow up safety study using a modified system in volunteers. Anaesthesia 2002;57:387-403.

28 Graham CA, Beard D, Oglesby AJ, et al. Rapid sequence intubation in Scottish urban emergency departments. Emerg Med J 2003;20:3-5.

29 Hewitt SM, Hartley RH. Manipulation under sedation in the accident and emergency department. J Accid Emerg Med 1994;11:186-8. 